\title{
Green Synthesis of Silver Nanoparticles from Caesalpinia gilliesii (Hook) leaves: antimicrobial activity and in vitro cytotoxic effect against BJ-1 and MCF-7 cells
}

\author{
Mahmoud Emam ${ }^{1 *}$, Mohamed A. El Raey ${ }^{1}$, Wael H. Eisa ${ }^{2}$, Alaadin E. El- Haddad ${ }^{3}$, Samir M. Osman ${ }^{3}$, \\ Mohamed A. El-Ansari ${ }^{1}$, Abdel-Gawad M. Rabie ${ }^{4}$ \\ ${ }^{1}$ Department of Phytochemistry and Plant Systematics, National Research Centre, Dokki, Cairo, Egypt. \\ ${ }^{2}$ Spectroscopy Department, Physics Division, National Research Centre, Dokki, Cairo, Egypt. \\ ${ }^{3}$ Department of Pharmacognosy, Faculty of Pharmacy, October 6 University, Giza, Egypt. \\ ${ }^{4}$ Department of Chemistry, Faculty of Science, Ain Shams University, Abbassia, Cairo, Egypt.
}

\begin{tabular}{l} 
ARTICLE INFO \\
\hline Article history: \\
Received on: 09/05/2017 \\
Accepted on: 26/06/2017 \\
Available online: 30/08/2017 \\
\hline Key words: \\
Silver nanoparticles, Total \\
phenolic \& flavonoid, \\
Antimicrobial, Anticancer, \\
Caesalpinia gilliesii.
\end{tabular}

\begin{abstract}
Green synthesis of silver nanoparticles using Caesalpinia gilliesii (Hook) leaves extract $(70 \% \mathrm{MeOH})$ for the first time as a reducing agent were investigated for their antimicrobial and cytotoxic activity (using the MTT assay). After exposing the oxidizing agent of silver ions to $C$. gilliesii leaves extract, the rapid reduction in the solution is observed due to the construction of silver nanoparticles. The prepared nanoparticles were elucidated by using UV-visible spectroscopy, Fourier Transforms infrared spectroscopy (FT-IR) and transmission electron microscope (TEM). The purified silver nanoparticles demonstrated promising antimicrobial activity against tested pathogens than hydroalcoholic extract. Cell viability by using the MTT assay demonstrated cytotoxic activity of the synthesized Ag NPs with C. gilliesii against normal skin fibroblast (BJ-1) and human breast cancer cell (MCF-7) with $\mathrm{IC}_{50}=80.1$ and $36.5 \mu \mathrm{g} / \mathrm{mL}$ at 48 hours incubation, respectively. Depending on the phenolic and flavonoid contents, $C$. gilliesii could be used for simple, nonhazardous, eco-friendly, cost-effective and efficient synthesis of Ag NPs that can be applied into medicinal field.
\end{abstract}

\section{INTRODUCTION}

The scientists all over the world always look for new and useful applications to humanity. Especially, the emergence of drug resistance is a significant problem due to misuse of antibiotics policy inside the countries that encourage us to develop alternative antimicrobial drugs from medicinal plants (Parekh et al., 2005; Bagiu et al., 2012). Moreover, the toxicity of natural products has attracted the scientists for preparations as

* Corresponding Author

Email: mahmoudemamhegazy2020 @ gmail.com,

Mobile: 00201063802898 antitumor agents that elevate people's health without detectable adverse effect (Nazarizadeh et al., 2013).

Nanoscience is considered one of the latest sciences which have attracted the attention of scientists. This is a new field that incorporates the fabrication and usage of nanoscale size materials to various applications (Rao et al., 2013; Filippo et al., 2010; Vivek et al., 2012), especially it's clean, non-toxic and ecofriendly (Jayaseelan et al., 2013).

Several extracts of plants, marines and microorganisms have been reported for the preparation of silver nanoparticles (Seema et al., 2010). As though, the potential of natural sources as bioactive materials for the preparation of nanoparticles and their compatibility with biological systems is not fully discussed. 
All approaches come up to give hope to be applied in large scale, for commercial applications by managing different physical and chemical parameters or genetically modified microbes' production that overmuch characteristic reducing agents and thereby, controlling biological nanoparticles resulted (Kannan et al., 2010), which reacts as a capping agent and prevent the nanoparticles accumulation. Phytoconstituents of plant extracts such as phenolics, terpenoids, plant enzymes and their derivatives react as reducing agents in the presence of metal sources for the formation of Ag NPs (Jacob et al., 2011; Thakkar et al., 2010). Moreover, some plant extracts have been explored in the production of metallic nanostructures under different environmental conditions. Nevertheless, in some cases, plants can absorb metals from the surrounding environment and accumulate them as nanostructures form inside the tissues (Quester et al., 2013). Leguminosae (Fabaceae) family is the second largest flowering plants that exceed in the number of genera and species. It is widespread in distribution, divided into three sub-families: Mimosaceae; Caesalpinacae and Papilionaceae. Caesalpinacae demonstrates approximately $11 \%$ of the identified legume flora (Kirkbride, 1986), mostly equatorial and sub equatorial in allocation. Many species of Caesalpinia used in folk medicine, like Caesalpinia bonducella seeds (Rao et al., 1994), C. digyna and C. sappan (Penpun et al., 2005) and were reported as antioxidant (Saenjum et al., 2010; Shukla et al., 2009), antiinflammatory (Chakraborthy et al., 2009; Sagar et al., 2009), hepatoprotective, antibiotic (Tasleem et al., 2009), antidiabetic (Kannur et al., 2006; Farook et al., 2011), antiviral (Jiang et al., 2002 a, b), and anticancer (Nakamura et al., 2002) activities. As, the plant family is rich in nitrogen compounds, saponins, terpenoids, glycosides derivatives and phenolics (Sivasankari et al., 2010; Banskota et al., 2003; Kalauni et al., 2006; Jadhav et al., 2003). Caesalpinia gilliesii (Hook) (Yellow Bird of Paradise) is a fast growing tree with Argentine nationality (South America). It grows in Egypt (Borg El Arab) and cultivated in private farms in Egypt (El-qanater El khairia). Previous preliminary phytochemical screening on leaves extract manifested the existence of carbohydrates, glycosides, saponins, phenolics, fats and terpenoids with different ratios (Osman et al., 2013). The present work aimed to estimate the total content of Phenolics (TPC) and Flavonoids (TFC) in the hydroalcoholic extract of $C$. gilliesii leaves, synthesize, characterize, evaluate antimicrobial activity and cytotoxicity effects on both Skin normal human cell line (BJ-1) and human breast cancer cells (MCF-7) of AgNPs obtained from C. gilliesii through various characterization techniques like UVvisible spectroscopy, transmission electron microscope (TEM) and Fourier Transforms infrared spectroscopy (FTIR). To our knowledge, the preparation of Ag NPs by $C$. gilliesii has not been discussed yet.

\section{MATERIAL AND METHODS}

Materials

Silver nitrate $\left(\mathrm{AgNO}_{3}\right.$, Merck), methanol (HPLC, SD Fine-Chem Limited), other chemicals and solvents used were of high grade unless mentioned and were covered from Egyptian market.

\section{Collection and Identification of Plant}

Caesalpinia gilliesii (bird of paradise) [(Wall. ex Hook.)] were harvested from Egypt (Borg El Arab) in May 2015. The taxonomical characteristics were approved (Osman et al., 2016) and kept in the herbarium of phytochemistry and plant systematics, pharmaceutical and drug industrial research division, National Research Centre, Dokki, Cairo, Egypt (CAIRC) (M-130) 2015.

\section{Plant Extract Preparation}

Freshly collected leaves plant materials were washed several times with domestic water then distilled water after that drying in shade for 8 days at room temperature for 7 days. Hydroalcoholic extract $(70 \%)$ of leaves by maceration were prepared. The obtained extract was dried then powdered, stored at $4{ }^{\circ} \mathrm{C}$ and used for further investigation.

\section{Estimation of Total Phenolic Content}

The total phenolic content (TPC) was calculated as gallic acid equivalent (mg GAE) per $g$ of sample according to the FolinCiocalteu procedure (Zilic et al., 2012).

\section{Estimation of Total Flavonoid Content}

The total flavonoid content (TFC) was quantitated as catechin equivalent (mg CE) per g of sample (Zilic et al., 2012) using aluminum chloride $\left(\mathrm{AlCl}_{3}\right)$ colorimetric assay.

\section{Biosynthesis of Ag NPs}

To study the effect of extract quantity on the reduction and the size of the biosynthesized nanoparticles. At room temperature, $\mathrm{Ag}$ NPs were synthesized by the reduction of $10 \mathrm{~mL}$ of $\mathrm{AgNO}_{3}$ solution of constant concentration $(1 \mathrm{mM})$ with different concentration of $C$. gilliesii extract $(100 \mu \mathrm{l}$ to $300 \mu \mathrm{l})$ from the stock solution $(0.04 \mathrm{~g}$ extract $/ 10 \mathrm{ml}$ solvent $)$. Also, shake the prepared mixture with hand and allowed to stand in the dark (r.t).

The obtained Ag NPs were purified by repeated centrifugation $(10,000 \mathrm{rpm} / 20 \mathrm{~min}$ ) followed by redispersion in deionized water. This process was repeated twice to avoid undesirable matter and isolate the pure Ag NPs (Zayed et al., 2015).

\section{Description of the Biosynthesized Ag NPs}

The V-630 UV-Vis spectrophotometer (Jasco, Japan) was used to determine the band metal wave length. Transmission electron microscope (TEM) (JEOL-JEM-1011, Japan) was used to determine the shape and sizes of the Ag NPs. FTIR 6100 spectrometer (Jasco, Japan) exhibited the different functional groups of the prepared nanomaterials in the range of 4000-400 $\mathrm{cm}^{-1}$ (Zayed et al., 2015). 


\section{Evaluation of antimicrobial activity}

Gram-positive, gram-negative bacterial pathogens and yeast were used to test the antimicrobial activity of $C$. gilliesii extract and Ag NPs by the agar well diffusion method (Perez et al., 1990). After cooling and solidifying the media, $100 \mu \mathrm{L}$ of the tested compound solution prepared by dissolving $(40 \mathrm{mg} / \mathrm{ml})$ hydroalcoholic extract of $C$. gilliesii and $(4 \mathrm{mg} / \mathrm{ml})$ of $C$. gilliesii Ag NPs as stock solutions were loaded per well, then incubated for $24 \mathrm{~h}$ at $37^{\circ} \mathrm{C}$. Distilled water (DW) were used to dissolve negative control. Also, $50 \mu \mathrm{g} / \mathrm{ml}$ of both Vancomycine and ketoconazole were prepared as standard. After incubation, the calculated average zone of inhibition in millimeters $(\mathrm{mm})$ is recorded in Table 2.

\section{Minimum Inhibitory Concentration (MIC) determination}

The bacteriostatic activity of tested samples (inhibition zones (IZ) $\geq 16 \mathrm{~mm}$ ) was then evaluated using the two-fold serial dilution technique (Scott, 1998). The final concentrations of the solution were $500,250,125$ and $65 \mu \mathrm{g} / \mathrm{ml}$. The concentration which showed no growth it considered the minimum inhibitory concentration (MIC).

\section{Evaluation of Cytotoxic activity \\ Cell culture}

Human Caucasian breast adenocarcinoma (MCF-7) and Skin normal human cell line (BJ-1) were maintained in RPMI and DMEM F12 medium, respectively. All media was supplemented with $10 \%$ fetal bovine serum, incubated at $37{ }^{\circ} \mathrm{C}$ in $5 \% \mathrm{CO}_{2}$ and $95 \%$ humidity. Cells were sub-cultured using trypsin $0.15 \%$.

\section{Cell viability assay}

Cell viability was estimated by MTT assay (Mosmann, 1983). Briefly, 10000 cells per well of MCF-7 and BJ-1 cell lines (in 96 well plates) were seeded. After $24 \mathrm{~h}$, the medium was changed to serum-free medium containing a final concentration of the samples of $100 \mu \mathrm{g} / \mathrm{ml}$ in triplicates. The cells were treated for $48 \mathrm{~h}$. Doxorubicin was used as positive control $(100 \mu \mathrm{g} / \mathrm{ml})$ and $0.5 \%$ DMSO was used as negative control (Thabrew et al., 1997; Menshawi et al., 2010). The calculation of the cytotoxicity $\%=$ $\left[\left(1-(\operatorname{av}(\mathrm{x}) /(\operatorname{av}(\mathrm{NC}))]^{*} 100\right.\right.$

(Where; Av: average, X: absorbance of sample \& NC: absorbance of negative control)

The absorbance was calculated at $595 \mathrm{~nm}$ and a reference wavelength of $620 \mathrm{~nm}$. Moreover, $\mathrm{IC}_{50}$ was calculated by using SPSS 11 program (Bassyouni et al., 2014).

\section{RESULTS AND DISCUSSION}

\section{Estimation of Total Phenolic Content}

The TPC for hydroalcoholic extract was estimated by using gallic acid as standard. The gallic acid concentration (5-50 $\mu \mathrm{g})$ conformed to Beer's Law at $725 \mathrm{~nm}$ with a regression coefficient $\left(\mathrm{R}^{2}\right)=0.9985$. The plot has a slope $(\mathrm{m})=0.0242$ and intercept $=0.0211$. The equation of standard curve is $\mathrm{Y}=0.0242 \mathrm{X}$ +0.0211 (Figure 1 and Table 1).

\section{Estimation of Total Flavonoid Content}

The TFC of the hydroalcoholic extract was measured with the aluminium chloride colorimetric assay using Catechin as standard. The Catechin solution of concentration $(5-100 \mu \mathrm{g})$ conformed to Beer's Law at $510 \mathrm{~nm}$ with a regression co-efficient $\left(\mathrm{R}^{2}\right)=0.9989$. The plot has a slope $(\mathrm{m})=0.0048$ and intercept $=$ 0.0091. The equation of standard curve is $\mathrm{y}=0.0048 \mathrm{x}+0.0091$ (Figure 2 and Table 1).

TPC and TFC calculated from the previous standard curves as showed at Table 1 that confirm the existence of phenolics and flavonoids structures.

Table 1: Results of total phenolic and flavonoid content for C. gilliesii leaves extract.

\begin{tabular}{ccc}
\hline Concentration of extract & $\begin{array}{c}\text { Phenolic content (mg of gallic } \\
\text { acid equivalent/ g dry material) }\end{array}$ & $\begin{array}{c}\text { Flavonoid content (mg of catechin } \\
\text { equivalent/ g dry material) }\end{array}$ \\
\hline Hydroalcoholic extract, $20 \mathrm{mg} / 2 \mathrm{ml}$ & $80.07438 \mathrm{mg}-\mathrm{GAE} / \mathrm{gm}$ & $35.375 \mathrm{mg}-\mathrm{CE} / \mathrm{gm}$ \\
\hline
\end{tabular}

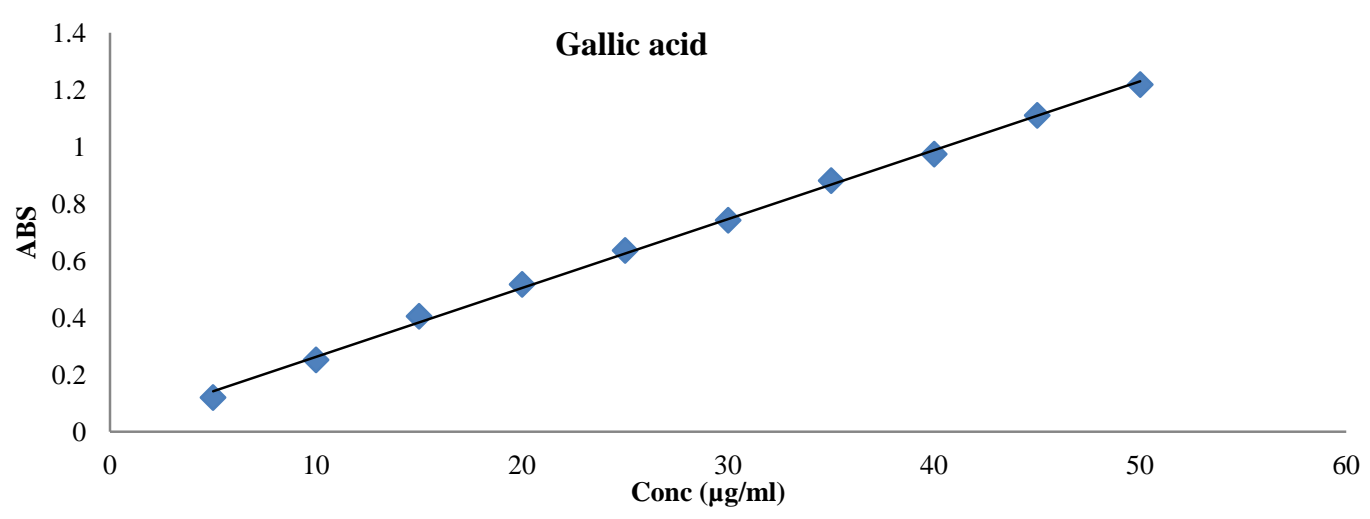

Fig. 1: Total phenolic content for standard gallic acid. 


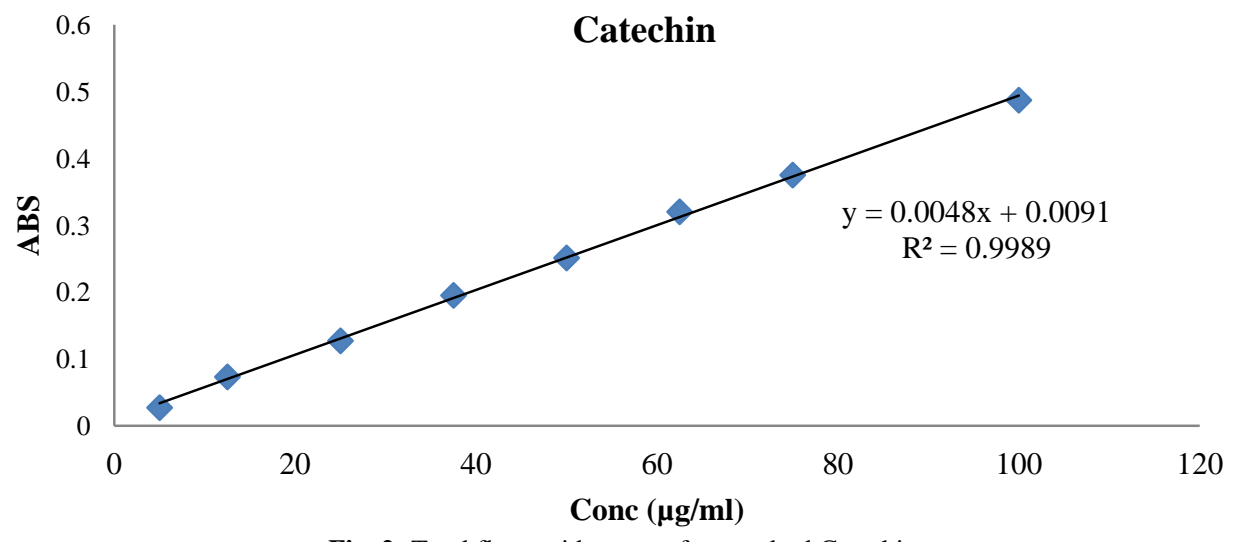

Fig. 2: Total flavonoid content for standard Catechin.

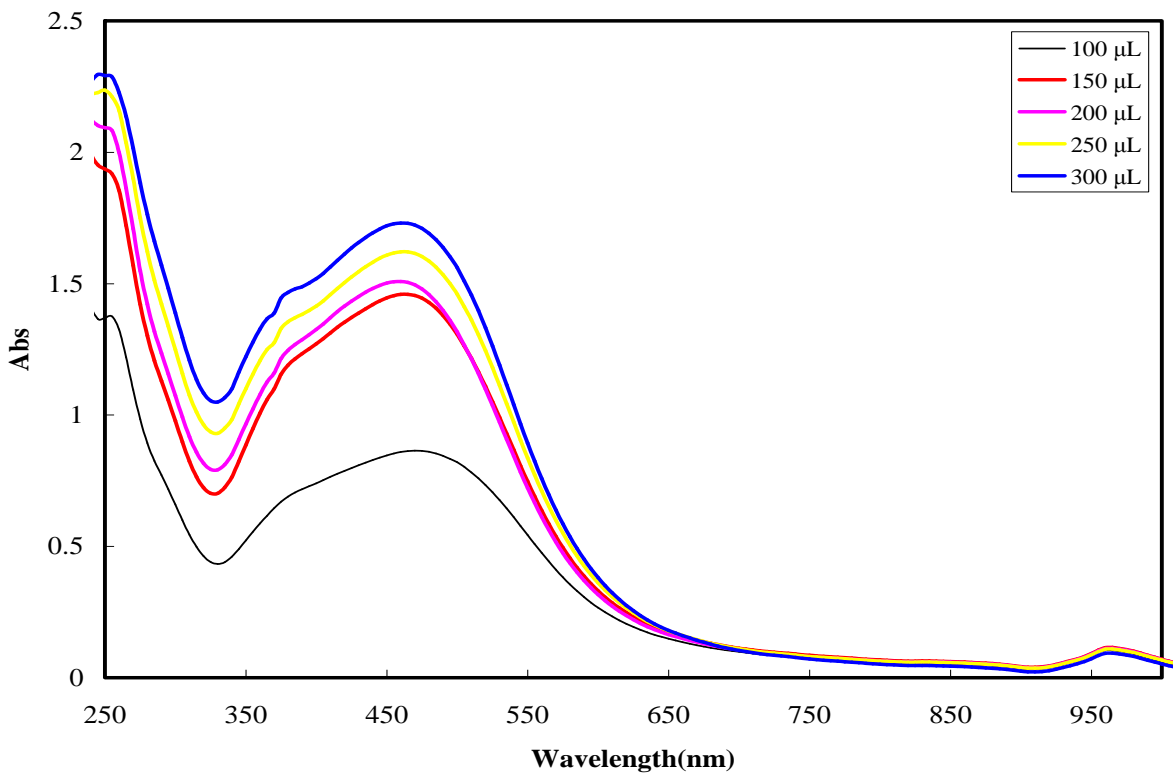

Fig. 3: the SPR band of Ag nanoparticles recorded by UV-vis spectra as a function of varying addition of $C$. gilliesii.

\section{UV-vis Spectroscopic Studies}

Ag nanoparticle dispersions are characterized by their brilliant colors. The appearance of the yellowish brown color is because of the surface plasmon resonance (SPR) in the reaction mixture has been taken as an evident for the formation of $\mathrm{Ag}$ nanoparticles (Rivero et al., 2013). Figure 3 illustrates the UV-vis spectra of $\mathrm{Ag}$ nanoparticles formed by adding different concentrations of $C$. gilliesii to $10 \mathrm{~mL}$ of $10^{-3} \mathrm{M} \mathrm{AgNO}_{3}$ solution. The as-prepared samples show an absorption in the visible region at $465-475 \mathrm{~nm}$ due to the SPR band. The intensity of the SPR band grows with the incremental addition of $C$. gilliesii. The increasing intensity of the SPR band indicates that more $\mathrm{Ag}^{+}$ions are reduced to $\mathrm{Ag}$ nanoparticles. The increased amounts of the extract mean that there are large numbers of functional groups available for the reduction and capping of the Ag nanoparticles. Furthermore, the SPR band exhibits a blue shift (from 470 to $455 \mathrm{~nm}$ ) as the extract quantity increases from 100 to $200 \mu \mathrm{L}$ and then it moves toward the longer wavelengths (from $455 \mathrm{~nm}$ to $460 \mathrm{~nm}$ ) as the extract quantity increases from 200 to $300 \mu \mathrm{L}$. this behavior could be discussed in the light of the law of mass action i.e. the reaction rate relates directly to the reactants concentration. Hence, it could be concluded that with increasing $C$. gilliesii concentration, the reaction rate increases. Increasing the reaction rate resulted in a faster reduction of $\mathrm{Ag}^{1+}$ ions which in turn enhances the nucleation rate. Thus, the blue shift of the SPR is a consequence of the formation of smaller $\mathrm{Ag}$ nanoparticles. Further addition of $C$. gilliesii extract enhances the growth rate to produce bigger particles which are reflected in the red shift of the SPR (Zayed et al., 2015) as it showed in Figure 3.

\section{FTIR Spectroscopic Studies}

The phytochemical results show that the leaves extract of C. gilliesii is consisting of a complex mixture of phytochemicals such as saponines, coumarin derivatives, flavonoids, plant sterols, 
carbohydrates or glycosides, tannins, cardiac glycosides and cyanogenic glycosides (Osman et al., 2013). These phytochemical species are rich in hydroxyl and amino groups. Several reports attributed the reduction of the metal nanoparticles to the presence of such functional groups (Rai et al., 2013; Thakkar et al., 2010; Iravani et al., 2013; Dauthal et al., 2016).

Hence, the FTIR is a sensitive tool for determining the functional groups responsible for the Ag nanoparticles reduction. Figure 4 showed the FTIR spectra of the $C$. gilliesii-stabilized Ag nanoparticles as compared with that of the naked extract. The spectrum of $C$. gilliesii extract exhibit a broad IR peak spread over the spectral region $\left(3600-3000 \mathrm{~cm}^{-1}\right)$. The IR bands in this region are attributed to the stretching vibrations of the $-\mathrm{OH}, \mathrm{N}-\mathrm{H}$ and $\mathrm{C}-\mathrm{H}$ groups (Samfira et al., 2015). The IR signal at $3395 \mathrm{~cm}^{-1}$ was assigned to the $(-\mathrm{OH})$ group whereas that at $3190 \mathrm{~cm}^{-1}$ was due to the stretching vibration of amino groups $(-\mathrm{N}-\mathrm{H})$ present in proteins (Zayed et al., 2015). The bending vibrational peak of ($\mathrm{NH}$ ) group was remarked at $1616 \mathrm{~cm}^{-1}$ while a broad IR peak was found at $1408 \mathrm{~cm}^{-1}$ was due to in-plane bending of $(-\mathrm{OH})$ of Phenol or tertiary alcohol. The IR band located at $1062 \mathrm{~cm}^{-1}$ is revealed to the stretching vibration of $(-\mathrm{C}-\mathrm{N})$ aromatic and aliphatic amines (Barth 2000). Upon interaction with $\mathrm{AgNO}_{3}$, four more remarkable changes on FTIR spectra were remarked. First, the $(-\mathrm{OH})$ band was sharpened and shifted to $3424 \mathrm{~cm}^{-1}$ while that of amino group was shifted to $3236 \mathrm{~cm}^{-1}$. Second, the $(-\mathrm{NH})$ bending was shifted to the higher energy side at $1624 \mathrm{~cm}^{-1}$. Third, the appearance of the new peak at $1245 \mathrm{~cm}^{-1}$ was attributed to the (-C-O) bending (Butnariu and Giuchici, 2011). Fourth, the $(-\mathrm{C}-$ N) stretching vibration was intensified and slightly shifted to 1076 $\mathrm{cm}^{-1}$. These spectroscopic results ascribed the reducing potential of the $C$. gilliesii extract to the presence of hydroxyl and amino groups present within its phytochemicals.

\section{TEM Studies}

The shape and size of the as-prepared Ag nanoparticles are evaluated using the HRTEM technique. Figure $5(a, b)$ displays the TEM image and the histogram of the particle distribution of the prepared Ag NPs. It can be seen that the as-prepared nanoparticles are mainly spherical in shape with particle size varies between 3-6 nm. The particles are separated from each other which reflect the capping action of the plant extract in the preparation process.

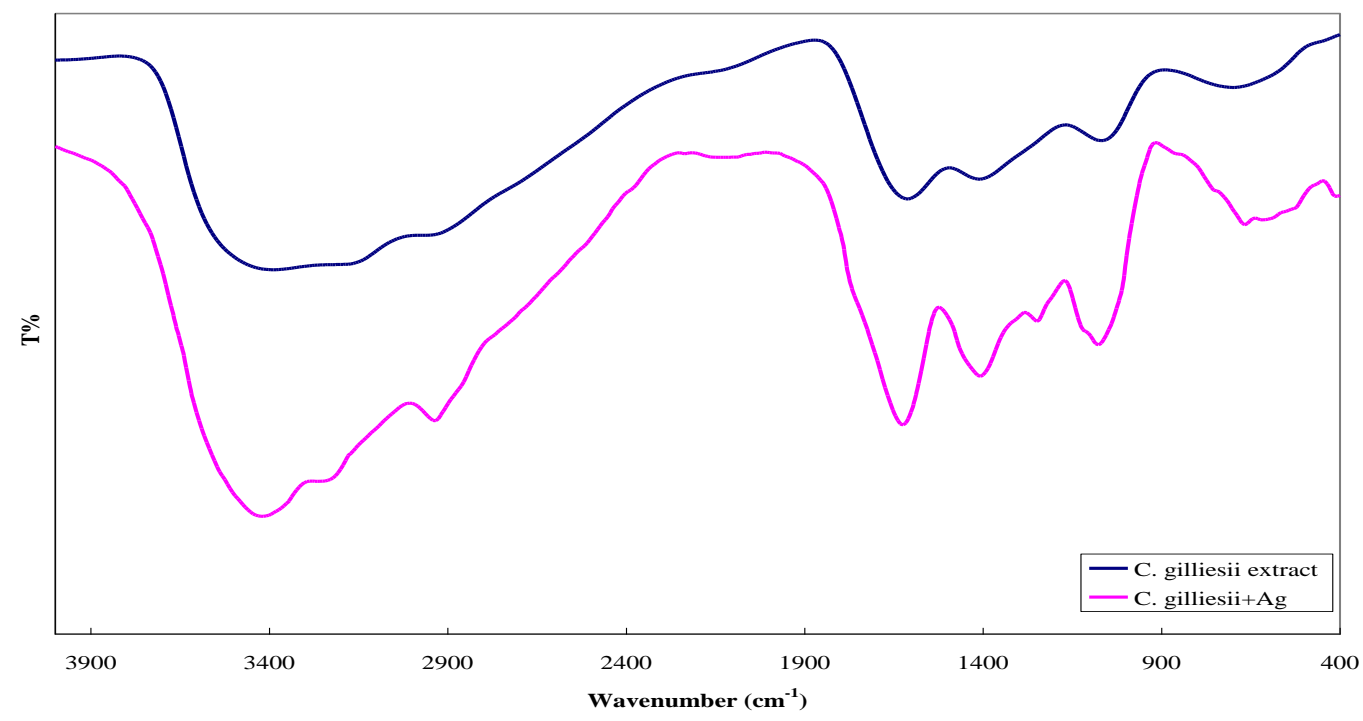

Fig. 4: FTIR spectra of extract stabilized Ag nanoparticles as compared with that of naked plant extract.
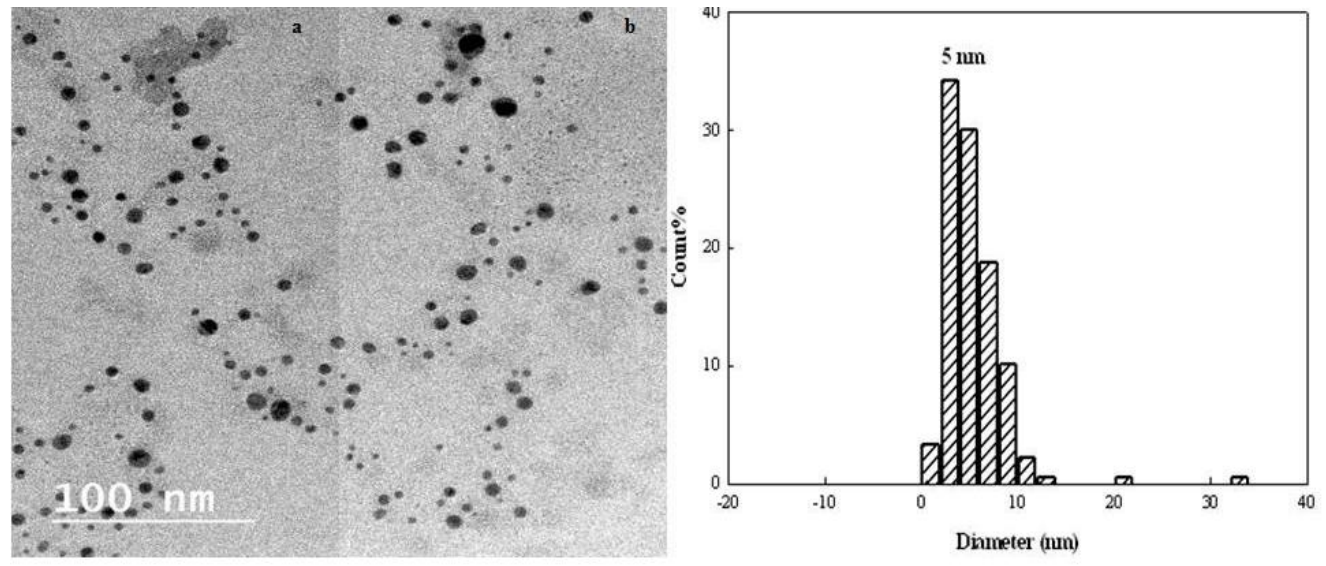

Fig. 5: The TEM images of C. gilliesii.-stabilized Ag nanoparticles (a) $250 \mu \mathrm{L}$ and (b) $300 \mu \mathrm{L}$. 


\section{Antimicrobial Activity}

Challenges in antibiotic resistance of human pathogens encourages us to find new natural alternates to beat this tackling. The antimicrobial activity of hydroalcoholic extract of $C$. gilliesii inhibited the growth of bacteria and yeast in varying degree of inhibition (Table 2).

But, synthesized Ag NPs of $C$. gilliesii extract showed the highest activity against all tested pathogens compared with hydroalcoholic extract as presented at Table 2 and Table 3 that showed the MIC values of Ag NPs for different pathogens in $(\mu \mathrm{g} / \mathrm{ml})$.

Bioactive compound capping, such as redox system play an important roles in Ag NPs formation. The concentration and the small size of the prepared Ag NPs may be play an important role for increasing its antimicrobial activity by easily diffusion or penetration of microorganism cell membrane and inhibited the growth (Manivasagan and Kim, 2015).

\section{Cytotoxicity of the Hydroalcoholic Extract and Ag NPs of C. gilliesii}

Recently, searching about antitumor drug derived from plant materials is increasing, because of their low adverse effects.
So, silver nitrate $\left(\mathrm{AgNO}_{3}\right)$, hydroalcoholic extract of $C$. gilliesii and Ag NPs were investigated to evaluate their cytotoxicity effect against both normal skin fibroblast (BJ-1) and breast cancer cell line (MCF-7). Hydroalcoholic C. gilliesii extract and Ag NPs showed cytotoxicity against MCF-7 with $4.2 \%$ and $96.5 \%$ at 100 $\mu \mathrm{g} / \mathrm{ml}$, respectively. Also, hydroalcoholic $C$. gilliesii extract and AgNPs exhibited cytotoxicity against BJ-1 with $33.3 \%$ and $70.5 \%$ at $100 \mu \mathrm{g} / \mathrm{ml}$, respectively. But, $\mathrm{AgNO}_{3}$ showed high cytotoxicity $\geq 90 \%$ at $12.5 \mu \mathrm{g} / \mathrm{ml}$. By ignoring the physical parameters of the Ag NPs, under aerobic conditions their toxicity only relied on the concentration of the $\mathrm{Ag}^{+}$released. So, we must repeat washing of Ag NPs prepared as much as possible to avoid toxicity of silver ion released. For the most active samples, a dose response study was made to calculate their $\mathrm{IC}_{50}$ values (Table 4).

Although Ag NPs have demonstrated effective antimicrobial and cytotoxic activities, the mechanisms of action of microorganisms and cell death have not been obviously confirmed yet. It has been suggested that $\mathrm{Ag}^{+}$released from $\mathrm{Ag}$ NPs can react with $(-\mathrm{SH})$ groups which upsetting their respiration mode and the reaction of $\mathrm{Ag}+$ with bases and phosphorus groups of DNA inhibited the DNA replication and thus cell death (Matsumura et al., 2003; Prabhu and Poulose, 2012).

Table 2: Antimicrobial activity expressed as inhibition diameter zones in millimeters ( $\mathrm{mm}$ ) of chemical compounds against the pathological strains based on well diffusion assay.

\begin{tabular}{|c|c|c|c|c|c|c|c|}
\hline \multirow[b]{2}{*}{$\begin{array}{l}\text { Chemical } \\
\text { compound }\end{array}$} & \multicolumn{2}{|c|}{ Gram positive bacteria } & \multicolumn{4}{|c|}{ Gram negative bacteria } & \multirow{2}{*}{$\begin{array}{c}\text { Yeast } \\
\text { Candida } \\
\text { Albicans } \\
\text { NRRL Y-477 }\end{array}$} \\
\hline & $\begin{array}{c}\text { Staphelococcus } \\
\text { aureus } \\
\text { ATCC } 43300 \\
\end{array}$ & $\begin{array}{c}\text { Streptococcus } \\
\text { pyogenes } \\
\text { ATCC19615 } \\
\end{array}$ & $\begin{array}{l}\text { Proteus } \\
\text { spp }\end{array}$ & $\begin{array}{c}\text { Salmonella typhimurim } \\
\text { ATCC14028 }\end{array}$ & $\begin{array}{c}\text { Pseudomonas. } \\
\text { aeroginosa } \\
\text { ATCC278223 } \\
\end{array}$ & $\begin{array}{l}\text { E. coli } \\
\text { ATCC } \\
25922 \\
\end{array}$ & \\
\hline Hydroalcoholic C. gilliesii ext. & 18 & 17 & 13 & N.A. & 13 & 12 & 18 \\
\hline AgNPs of C. gilliesii & 23 & 19 & 16 & 17 & 19 & 21 & 20 \\
\hline Vancomycine & 28 & 30 & 24 & 25 & 24 & 22 & N.A. \\
\hline Ketoconazole & N.A. & N.A. & N.A. & N.A. & N.A. & N.A. & 22 \\
\hline
\end{tabular}

N.A. (No activity).

Table 3: Minimum inhibitory concentration $(\mu \mathrm{g} / \mathrm{ml})$ against the pathological strains based on two fold serial dilution technique

\begin{tabular}{|c|c|c|c|c|c|c|c|}
\hline \multirow[b]{2}{*}{$\begin{array}{l}\text { Chemical } \\
\text { compound }\end{array}$} & \multicolumn{2}{|c|}{ Gram positive bacteria } & \multicolumn{4}{|c|}{ Gram negative bacteria } & \multirow{2}{*}{$\begin{array}{c}\text { Yeast } \\
\text { Candida } \\
\text { Albicans } \\
\text { NRRL Y-477 }\end{array}$} \\
\hline & $\begin{array}{c}\text { Staphelococcus } \\
\text { aureus } \\
\text { ATCC } 43300 \\
\end{array}$ & $\begin{array}{c}\text { Streptococcus } \\
\text { pyogenes } \\
\text { ATCC19615 } \\
\end{array}$ & Proteus spp & $\begin{array}{r}\text { Salmonella } \\
\text { typhimurim } \\
\text { ATCC14028 } \\
\end{array}$ & $\begin{array}{c}\text { Pseudomonas. } \\
\text { aeroginosa } \\
\text { ATCC278223 } \\
\end{array}$ & $\begin{array}{l}\text { E. coli } \\
\text { ATCC } \\
25922 \\
\end{array}$ & \\
\hline Hydroalcoholic C. gilliesii ext. & 250 & 250 & - & - & - & - & 500 \\
\hline AgNPs of C. gilliesii & 65 & 125 & 500 & 500 & 250 & 125 & 65 \\
\hline Vancomycine & 65 & 65 & 65 & 65 & 65 & 65 & N.A. \\
\hline Ketoconazole & N.A. & N.A. & N.A. & N.A. & N.A. & N.A. & 65 \\
\hline
\end{tabular}

Table 4: $\mathrm{IC}_{50}(\mu \mathrm{g} / \mathrm{ml})$ against BJ1 and MCF-7

\begin{tabular}{|c|c|c|}
\hline \multicolumn{3}{|c|}{$\mathrm{IC}_{50}(\mu \mathrm{g} / \mathrm{ml})$ of silver nano particle of $C$. gilliesii extract against Doxorubicin } \\
\hline & Ag NPs & Doxorubicin \\
\hline BJ-1 & 80.1 & 31.6 \\
\hline MCF-7 & 36.5 & 26.1 \\
\hline
\end{tabular}




\section{CONCLUSION}

Due to the presence of phenolic and flavonoid structures that can be used as both reducing and capping agents into the hydroalcoholic extract of $C$. gilliesii leaves revealed that the silver nanoparticles formed, that possesses potent antimicrobial activity and promising anticancer activity against breast cancer cell lines and safe against normal skin fibroblast cell lines. This study has opened up the possible way for synthesizing multi-drug resistant antimicrobial Ag NPs using natural biomolecules which could be used in pharmaceutical industry. To the best of our knowledge, this is the first article on the green synthesis of metallic Ag NPs using $C$. gilliesii leaves extract.

\section{ACKNOWLEDGEMENTS}

Authors thank the group of Bioassay-Cell Culture and Microbiology Laboratories, National Research Centre, Egypt.

Financial support and sponsorship: This work was supported by National Research Centre (NRC, Ph. D. fund no. 2/4/5).

Conflict of Interests: There are no conflicts of interest.

\section{REFERENCES}

Arif T, Mandal TK, Kumar N, Bhosale JD, Hole A, Sharma GL, Padhi MM, Lavekar GS, Dabur R. In vitro and in vivo antimicrobial activities of seeds of Caesalpinia bonduc Roxb. Journal of Ethnopharmacology, 2009; 123:177-180.

Bagiu RV, Vlaicu B, Butnariu M. Chemical composition and in vitro antifungal activity screening of the Allium ursinum L (Liliaceae). International journal of molecular sciences. 2012; 13:1426-1436.

Banskota A, Attamimi F, Usia T, Linn T, Tezuka Y, Kalaunia $\mathrm{S}$, Kadota S. Novel norcassane-type diterpene from the seed kernels of Caesalpinia crista. Tetrahedron Letters, 2003; 44:6879-6882.

Barth A. The infrared absorption of amino acid side chains. Prog Biophys Mol Biol, 2000; 74:141-173.

Bassyouni FA, Abu-Baker SM, Mahmoud K, Moharam M, ElNakkady SS, Abdel-Rehim M. Synthesis and biological evaluation of some new triazolo[1,5-a]quinoline derivatives as anticancer and antimicrobial agents". RSC Advances, 2014; 4:24131-24141.

Chakraborthy S, Badujar S, Pardeshi R. Analgesic activity of chloroform extract of Caesalpinia pulcherrima. Journal of Pharmacy Research, 2009; 2:1199-1200.

Dauthal P, Mukhopadhyay M. Biosynthesis of Palladium Nanoparticles Using Delonix regia Leaf Extract and Its Catalytic Activity for Nitro-aromatics Hydrogenation. Ind Eng Chem Res, 2016; 55:95579577.

Din WM, Jin KT, Ramli R, Khaithir TM, Wiart C. Antibacterial Effects of Ellagitannins from Acalypha wilkesiana var. macafeana hort.: Surface Morphology Analysis with Environmental Scanning Electron Microcopy and Synergy with Antibiotics. Phytotherapy Research, 2013; 27:1313-1320.

Butnariu MV, Giuchici CV. The use of some nanoemulsions based on aqueous propolis and lycopene extract in the skin's protective mechanisms against UVA radiation. Journal of nanobiotechnology. 2011; 9(1):3.

El-Menshawi BS, Fayad W, Mahmoud K, El-Hallouty SM, ElManawaty M, Olofsson MH, Linder S. Screening of natural products for Therapeutic activity against solid tumors. Indian Journal of Experimental Biology, 2010; 48:258-264.

Farook M, Atlee C, Karimulla S, Mrunal D. Assessment of antidiabetic potential of Caesalpinia digyna root extract in STZ induced diabetic rats. IJPSR, 2011; 2:675-684.
Filippo E, Serra A, Buccolieri A, Manno D. Green synthesis of silver nanoparticles with sucrose and maltose: Morphological and structural characterization. J Non-Cryst Solids, 2010; 356:344-350.

Gohar AA, Lahloub MF, Niwa M. Antibacterial polyphenol from Erodium glaucophyllum. Zeitschrift für Naturforschung C, 2003; 58(9-10):670-674.

Iravani S, Zolfaghari B. Green Synthesis of Silver Nanoparticles Using Pinus eldarica Bark Extract. Biomed Res Int, 2013; 2013:1-5.

Jacob Z, Shalaev VM. Plasmonics Goes Quantum. Science, $2011 ; 334: 463-464$.

Jadhav N, Kaur N, Bhutani K. A new furanoditerpenoid marker for the distinction between the seeds of two species of Caesalpinia. Phytochem Anal, 2003; 14:315-318.

Jayaseelan C, Ramkumar R, Rahuman AA, Perumal P. Green synthesis of gold nanoparticles using seed aqueous extract of Abelmoschus esculentus and its antifungal activity. Ind Crop Prod, 2013; 45:423-429.

Jiang R, Cheng S, He Z, Huang X, But P, Wang H, Chan S, Ooi $\mathrm{V}, \mathrm{Xu} \mathrm{H}$, Mak T. Molecular Structures and Antiviral Activities of Naturally Occurring and Modified Cassane Furanoditerpenoids and Friedelane Triterpenoids from Caesalpinia minax. Bioorganic \& Medicinal Chemistry, 2002a; 10:2161-2170.

Jiang RW, But PP, Ma SC, Ye WC, Chana SP, Mak TCW. Structure and antiviral properties of macrocaesalmin, a novel cassane furanoditerpenoid lactone from the seeds of Caesalpinia minax Hance. Tetrahedron Letters, 2002b; 43:2415-2418.

Kalauni S, Awale S, Tezuka Y, Banskota A, Linn T, Asih P, Syafruddin D, Kadota S. Antimalarial Activity of Cassane- and Norcassane-Type Diterpenes from Caesalpinia crista and Their StructureActivity Relationship. Biol Pharm Bull, 2006; 29:1050-1052.

Kannan BN, Natarajan S. Biological synthesis of metal nanoparticles by microbes. Advances in Colloid and Interface Science, 2010; 156:1-13.

Kannur M, Hukkeri I, Akki S. Antidiabetic activity of Caesalpinia bonducella seed extracts in rats. Fitoterapia, 2006; 77:546549.

Kirkbride H, Phylogeny and classification of Pakistan Legumes. Pak J Bot, 1986; 18:287-299.

Latté KP, Kolodziej H. Antifungal effects of hydrolysable tannins and related compounds on dermatophytes, mould fungi and yeasts. Zeitschrift für Naturforschung C, 2000; 55:467-472.

Manivasagan P, Kim SK. 2015. Biosynthesis of nanoparticles using marine algae: A review. In Marine Algae Extracts: Processes, Products, and Applications; Kim SK, Chojnacka K, Eds.; Wiley-VCH: Weinheim, Germany.

Matsumura Y, Yoshikata K, Kunisaki SI, Tsuchido T. Mode of bactericidal action of silver zeolite and its comparison with that of silver nitrate. Appl Environ Microbiol, 2003; 69:4278-4281.

Mosmann T. Rapid colorimetric assays for cellular growth and survival: Application to proliferation and cytotoxicity assays. J Immunol Methods, 1983; 65:55-63.

Nakamura S, Kurosaki F, Arisawa M, Mukainaka T, Okuda M, Tokuda H, Nishino H, Pastore F. Cancer chemopreventive effects of constituents of Caesalpinia ferrea and related compounds. Cancer Letters, 2002; 177:119-124.

Nazarizadeh A, Mikaili P, Moloudizargari M, Aghajanshakeri S, Javaherypour S. Therapeutic Uses and Pharmacological Properties of Plantago major L . and its Active Constituents. J Basic Appl Sci Res, 2013; 3:212-221.

Osman SM, Alazzouni AS, Abdel Khalek SM, Koheil MA, ElHaddad AE. Phytoconstituents and Biological Activities of The Aerial Parts of Caesalpinia gilliesii (Hook) Family Caesalpinacae Growing in Egypt. Life Science Journal, 2013; 10:2418-2430.

Osman SM, El-Haddad AE, El-Raey MA, Abd El-Khalik SM, Koheil MA, Wink M. A New Octadecenoic Acid Derivative from Caesalpinia gilliesii Flowers with Potent Hepatoprotective Activity. Pharmacognosy Magazine, 2016; 12:332-336.

Parekh J, Jadeja D, Chanda S. Efficacy of Aqueous and Methanol Extracts of Some Medicinal Plants for Potential Antibacterial Activity. Turk J Biol, 2005; 29:203-210. 
Penpun W, Thawatchai P, Sindhchai K. The Antioxidant Activity of Caesalpinia sappan L. Heartwood in Various Ages. Naresuan University Journal, 2005; 13:43-52.

Perez C, Pauli M, Bazevque P. An antibiotic assay by the agar well diffusion method. Acta Biologiae et Medicine Experimentalis, 1990; 15:113-115.

Prabhu S, Poulose EK. Silver nanoparticles: Mechanism of antimicrobial action, synthesis, medical applications, and toxicity effects. Int Nano Lett, 2012; 2:32.

Quester K, Avalos-Borja M, Castro-Longoria E. Biosynthesis and microscopic study of metallic nanoparticles. Micron, 2013; 54:1-27.

Rai M, Yadav A. Plants as potential synthesiser of precious metal nanoparticles: progress and prospects. IET Nanobiotechnol, 2013; 7:117-124.

Rao KJ, Paria S. Green synthesis of silver nanoparticles from aqueous Aegle marmelos leaf extract. Mater Res Bull, 2013; 48:628-634.

Rao V, Dwivedi k, Swarup D. Hypoglycemic effect of Caesalpinia bonducella in rabbits. Fitoterapia, 1994; 65:245-247.

Rivero P, Goicoechea J, Urrutia A, Arregui F. Effect of both protective and reducing agents in the synthesis of multicolor silver nanoparticles. Nanoscale Research Letters, 2013; 8:101-109.

Saenjum C, Chaiyasut C, Kadchumsang S, Chansakaow S, Suttajit M. Antioxidant activity and protective effects on DNA damage of Caesalpinia sappan L. extract. Journal of Medicinal Plants Research, 2010; 4(15):1594-1600.

Sagar K, Ashok K, Chopra H, Singh M, Upadhyaya K. Analgesic and Antiinflammatory properties of Caesalpinia (BONDUC) Seeds. The Pharma Research, 2009; 1:54-59.

Samfira I, Rodino S, Petrache P, Cristina RT, Butu M, Butnariu M. Characterization And Identity Confirmation Of Essential Oils By Mid Infrared Absorption Spectrophotometry. DIGEST JOURNAL OF NANOMATERIALS AND BIOSTRUCTURES. 2015; 10(2):557-565.

Scott AC. 1989. Laboratory Control of Antimicrobial Therapy. In: Collee JG, Duguid JP, Fraser AG, Marmion BP. Mackie and MacCartney Practical Medical Microbiology. $13^{\text {th }}$ Ed, vol(2), Churchill Livingstone $161-181$.
Seema S, Naheed A, Anuradha P, Vidya NS, Ashok KG, Bodh RM. Synthesis of crystalline ag nanoparticles (AgNPs) from microorganisms. Mater Sci Appl, 2010; 1:1-7.

Shukla S, Mehta A, John J, Singh S, Mehta P, Prasad S. Antioxidant activity and total phenolic content of ethanolic extract of Caesalpinia bonducella seeds. Food and Chemical Toxicology, 2009; 47:1848-1851.

Sivasankari K, Janaky S, Sekar T. Evaluation of phytochemicals in select medicinal plants of the Caesalpinia species. Indian Journal of Science and Technology, 2010; 3:1118-1121.

Thabrew MI, Hughes RD, McFarlane IG. Screening of hepatoprotective plant components using a HepG2 cell cytotoxicity assay. J Pharm Pharmacol, 1997; 49:1132-1135.

Thakkar KN, Mhatre SS, Parikh RY. Biological synthesis of metallic nanoparticles. Nanomedicine, 2010; 6:257-262.

Vivek R, Thangam R, Muthuchelian K, Gunasekaran P, Kaveri $\mathrm{K}$, Kannan S. Green biosynthesis of silver nanoparticles from Annona squamosa leaf extract and its in vitro cytotoxic effect on MCF-7 cells. Process Biochem, 2012; 47:2405-2410.

Zayed M, Eisa W, Abdel-Moneam Y, El-kousy S, Atia A. Ziziphus spina-christi based bio-synthesis of Ag nanoparticles. Journal of Industrial and Engineering Chemistry, 2015; 23:50-56.

Zilic S, Serpen A, Akıllıg lu G, Gökmen V, Vancetovic J. Phenolic Compounds, Carotenoids, Anthocyanins, and Antioxidant Capacity of Colored Maize (Zea mays L.) Kernels. J Agric Food Chem, 2012; 60:1224-1231.

\section{How to cite this article:}

Emam M, El-Raey MA, Eisa WH, El-Haddad AE, Osman SM, ElAnsari MA, Rabie AM. Antimicrobial of Green Synthesis Silver Nanoparticles Using Extract of Caesalpinia gilliesii (Hook) leaves: and in Vitro Cytotoxic Effect against BJ1 and MCF-7 Cells. J App Pharm Sci, 2017; 7 (08): 226-233. 